\title{
Isolation of cell populations from the mare corpus luteum: comparison of mechanical and collagenase dissociation
}

\author{
C. Broadley ${ }^{1 *}$, G. S. Menzies ${ }^{2}$, T. A. Bramley ${ }^{2}$ and E. D. Watson ${ }^{1}$ \\ ${ }^{1}$ Department of Veterinary Clinical Studies, Royal (Dick) School of Veterinary Studies, University of \\ Edinburgh, Edinburgh EH25 9RG, UK; and ${ }^{2}$ Department of Obstetrics and Gynaecology, University of \\ Edinburgh, Centre for Reproductive Biology, 37 Chalmers Street, Edinburgh EH3 9EW, UK
}

\begin{abstract}
Corpora lutea were obtained from mares at days 3,10 and 14 after ovulation, and examined histologically. The morphology of isolated luteal cells obtained by either mechanical or collagenase dissociation of the tissue was examined and the cells stained to detect the steroidogenic enzyme $\Delta^{5}, \beta$-hydroxysteroid dehydrogenase. The ratio of large:small cells was significantly higher for cells obtained from mechanically dissociated luteal tissue than for cells obtained by collagenase dissociation $(P<0.01)$. Cells obtained by both mechanical and collagenase dissociation secreted progesterone, although neither cell population responded to exogenous gonadotrophin with an increase in progesterone secretion. Homogenates of equine luteal tissue bound ${ }^{125} \mathrm{I}$-labelled human $\mathrm{LH}$ with high affinity and specificity, and the specific activity and binding affinity of luteal LH receptors did not change significantly from day 3 , to days 10 and 14 after ovulation. However, mechanically dissociated cells on days 10 and 14 bound significantly more $\mathrm{LH}$ than did collagenasedissociated cells on these days $(P<0.05)$. These results indicate that (i) collagenase dissociation of mare luteal tissue yields a population of cells that is unrepresentative of the corpus luteum, and (ii) the mare corpus luteum is not responsive to LH in vitro at the stages examined.
\end{abstract}

\section{Introduction}

The functional control of the corpus luteum in humans and domestic animals has been reviewed recently by Baird (1992) and Wiltbank and Niswender (1992). In humans and domestic animals, the primary luteotrophin is LH. In vitro, LH enhances the secretion of progesterone from porcine luteal slices (Watson and Leask, 1975), bovine luteal tissue (Condon and Black, 1976) and from dissociated luteal cells from pigs, cattle and sheep (Lemon and Loir, 1977; Pate and Condon, 1982; Hoyer et al., 1988, respectively). The corpus luteum of these domestic species is composed of two distinct types of steroidogenic cell, which are thought to be derived from the follicular granulosa and theca interna layers. These cells differ in their secretory function: large luteal cells are thought to be derived from granulosa cells, secrete high basal amounts of progesterone and are unresponsive to LH; small luteal cells are thought to derive from thecal cells, have a low basal secretion of progesterone, but respond to LH with a dramatic increase in steroid secretion (Koos and Hansel, 1981; Fitz et al, 1982). Many of the properties of isolated luteal cells have been defined using isolated cell preparations obtained by collagenase dispersion (Simmons et al., 1976); however, it is known that cell

\footnotetext{
*Present address: Department of Cell Biology, University of Glasgow, Glasgow G12 8QQ, UK.

Received 8 October 1993
}

damage and specific loss of large cells can occur during this procedure (O'Shea et al., 1989; Nelson et al., 1992).

Although much is now known about the control of the corpus luteum in other domestic species, relatively little is known about the control of the mare corpus luteum. Oestrous cycle disorders such as dioestrous ovulations and prolonged retention of the corpus luteum in unmated mares are not uncommon. Furthermore, the mare is unusual in that secondary corpora lutea develop during pregnancy, suggesting that the regulatory mechanisms of the mare corpus luteum may differ from those in other species. In contrast to other domestic species (see above), only the granulosa cells are thought to contribute to the fully functional mare corpus luteum (Van Niekerk et al., 1975). Although collagenase dispersion of equine luteal tissue yields cells of different sizes (Kelly et al., 1988; Watson and Sertich, 1990), the steroidogenic potential of these cell populations is unclear, since increased progesterone secretion was not observed when LH was added to slices of equine luteal tissue (Condon et al., 1979), and the effect of gonadotrophin treatment on collagenase-dispersed equine luteal cells has been reported as either stimulatory (Kelly et al., 1988) or as having no effect (Watson and Sertich, 1990). However, the lack of response to LH was not due to the absence of LH receptors (Stewart and Allen, 1979; Roser and Evans, 1983).

The objective of this study was therefore to characterize the mare corpus luteum in terms of the different (steroidogenic) cell 
types present, the presence of $\mathrm{LH}$ receptors throughout the luteal phase, and the steroidogenic responsiveness of isolated luteal cell types. Preliminary studies of the cell populations obtained by mechanical and collagenase dissociation of the mare corpus luteum led us to carry out a more detailed comparison of the two cell-dispersion techniques.

\section{Materials and Methods}

\section{Materials}

hCG (Chorulon; 1500 iu hCG per ampoule) and pregnant mares' serum gonadotrophin (PMSG; Folligon; 1500 iu per ampoule) were purchased from Intervet Laboratories, Cambridge, UK. Equine LH (eLH E263B) and equine FSH (E276B) were obtained from H. Papkoff, San Francisco, CA. Mouse epidermal growth factor (mEGF) was the generous gift from K. Brown, Babraham, Cambridge, UK, and the GnRH agonist buserelin (D-[(tBu)Ser $\left.{ }^{6}\right] \mathrm{GnRH}$ ethylamide) was the kind gift of J. Sandow, Hoescht AG, Frankfurt. Highly purified hCG (CR-125), ovine $\mathrm{LH}$, ovine $\mathrm{FSH}$, and ovine and human prolactin were obtained from the Hormone Distribution Officer, NIAMDD, Bethesda, MD. ${ }^{125}$ I-Labelled hLH $\left(100 \mu \mathrm{Ci}_{\mu \mathrm{g}}{ }^{-1}\right)$ was purchased from K. Ferguson (Chelsea Hospital for Women, London). Collagenase $\mathrm{D}\left(0.34 \mathrm{U} \mathrm{mg}^{-1}\right)$ was purchased from Boehringer Mannheim (East Sussex). All other materials were obtained from Sigma Chemical Co. (Poole).

\section{Animals}

Twelve pony mares, $250-350 \mathrm{~kg}$ and $3-15$ years of age, were used in this study. Throughout the spring and summer, the mares exhibited normal patterns of oestrus and ovulation. During oestrus, follicular growth was monitored daily by real-time ultrasonography per rectum until ovulation was detected (day of ovulation = day 0 ). The ovary containing the corpus luteum was removed 3, 10 or 14 days after ovulation by colpotomy (Watson and Sertich, 1990). Acepromazine $\left(0.05 \mathrm{mg} \mathrm{kg}{ }^{-1}\right.$; C-Vet Ltd, Bury St Edmunds), rimifidine $\left(0.05 \mathrm{mg} \mathrm{kg}{ }^{-1}\right.$; Boehringer Ingleheim Ltd, Bracknell) and butorphanol $\left(0.05 \mathrm{mg} \mathrm{kg}^{-1}\right.$; Willow Francis, Crawley) were administered i.v. to induce sedation and analgesia. After a subsequent ovulation the remaining ovary was removed on day 3,10 or 14 of dioestrus. A blood sample was collected by jugular venepuncture immediately before surgery, and plasma was stored at $-20^{\circ} \mathrm{C}$ until it was analysed for progesterone.

\section{Processing of the corpus luteum}

After surgery, the corpus luteum was removed from the ovary; a piece of tissue was snap-frozen immediately in liquid nitrogen for LH binding analysis; and 2-3 wedges of tissue were placed in Bouin's fixative for histological analysis. Paraffin wax sections were prepared and stained with haematoxylin and eosin. Cell diameters were measured by randomly selecting six fields per slide and estimating the diameters of all the cells in each field using an ocular micrometer. At least four different sections and 200 cells for each stage were measured.

\section{Isolation and dissociation of luteal cells}

The remainder of the tissue was minced into pieces approximately $1 \mathrm{~mm}^{3}$ and placed in a $50 \mathrm{ml}$ centrifuge tube (Falcon, Becton Dickinson UK Ltd, Oxford) in $30 \mathrm{ml}$ of Hank's balanced salts solution (without divalent cations) buffered with $20 \mathrm{mmol}$ Hepes $1^{-1}$ (buffered HBSS; Flow Laboratories, Irvine). Cells were mechanically dissociated from the tissue by gently inverting the tube 10-15 times. The suspension was passed through a $100 \mu \mathrm{m}$ stainless steel mesh, the cells were collected by centrifugation $(400 \mathrm{~g}, 10 \mathrm{~min})$ and resuspended in buffered HBSS. One piece of the remaining tissue was placed in Bouin's fixative for histological examination. The rest was subjected to enzymatic digestion by the method of Simmons et al. (1976), but using collagenase $\mathrm{D}\left(0.34 \mathrm{U} \mathrm{mg}^{-1}\right)$. (This collagenase preparation was selected because it has a relatively low tryptic activity $\left(<0.1 \mathrm{U} \mathrm{mg}^{-1}\right.$ ) compared with other commercially available collagenase preparations, and is recommended for studies where functionality and surface protein integrity are important considerations.) The tissue was added to dissociation medium (buffered HBSS containing divalent cations, $10 \%$ fetal calf serum, $0.02 \%$ DNAse, $100 \mathrm{U}$ penicillin $\mathrm{ml}^{-1}, 100 \mu \mathrm{g}$ streptomycin $\mathrm{ml}^{-1}$ and $1 \mathrm{mg}$ collagenase $\mathrm{D} \mathrm{ml} \mathrm{m}^{-1}$ ) and incubated in a shaking water bath at $37^{\circ} \mathrm{C}$ for $45 \mathrm{~min}\left(3 \mathrm{ml} \mathrm{g}^{-1}\right.$ tissue). After digestion, the cells were washed twice with buffered HBSS and collected by centrifugation $(400 \mathrm{~g}$, $10 \mathrm{~min}$ ). Large and small cells in both mechanically and collagenase-dissociated cell preparations were counted using a haemocytometer. Cell viability was assessed using fluorescein diacetate (Rotman and Papermaster, 1966). Cytospin preparations of both mechanically dissociated and collagenasedissociated cells were stained with Diff-Quik ${ }^{(i ⿵}$ (Baxter, Thetford), or for the presence of $\Delta^{5}, \beta$-hydroxysteroid dehydrogenase (3 $\beta$-HSD) using the method of Payne et al. (1980).

\section{Culture of luteal cells}

Mechanically dissociated and collagenase-dissociated cells were suspended in culture medium (M199 and $20 \mathrm{mmol}$ Hepes $\mathrm{l}^{-1}$ containing $100 \mathrm{u}$ penicillin $\mathrm{ml}^{-1}$ and $100 \mu \mathrm{g}$ streptomycin $\mathrm{ml}^{-1}, \mathrm{pH} 7.2$ ) at a concentration of $10^{5} \mathrm{cells} \mathrm{ml}^{-1}$, and $200 \mu \mathrm{l}$ aliquots were added to multiwell tissue culture dishes (Falcon). Equine LH (10-500 $\mathrm{ng} \mathrm{ml}^{-1}$ ) or hCG $\left(0.1-100 \mathrm{iu} \mathrm{ml}^{-1}\right)$ were included in the incubation medium. The cells were incubated at $37^{\circ} \mathrm{C}$ under a humidified atmosphere of $5 \% \mathrm{CO}_{2}: 95 \%$ air for $2-6 \mathrm{~h}$ or for $20 \mathrm{~h}$. After incubation, the medium was collected, centrifuged at $400 \mathrm{~g}$ for $10 \mathrm{~min}$ to remove the cells and the supernatant stored at $-20^{\circ} \mathrm{C}$ until assayed.

\section{Progesterone assay}

Progesterone was assayed in unextracted plasma or culture medium by a double-antibody radioimmunoassay using a specific antiserum provided by R. Webb (The Roslin Institute, Midlothian), as described by Webb et al. (1985). The limit of detection of the assay was $0.1 \mathrm{ng} \mathrm{ml}^{-1}$ and the intra-assay and interassay coefficients of variation were $5.3 \%$ and $7.7 \%$, respectively. Standards were prepared in equine plasma or in culture medium and showed good parallelism. The 
principal crossreactivities of the antibody $(>1.0 \%)$ were with 11a-hydroxyprogesterone (22.67\%), 11-deoxycorticosterone

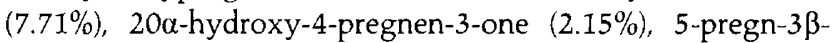
ol-20-one (1.48\%) and 5 $\alpha$-pregnane 3,20-dione (1.42\%) (C. Ashworth, personal communication). Progesterone concentration was adjusted for the number of cells and secretion was normalized for differences in the duration of incubation.

\section{LH binding assay}

Homogenates of equine luteal tissue or sonicated cells were incubated in triplicate with Tris-acetate buffer $\left(40 \mathrm{mmol} \mathrm{l}^{-1}\right.$, $\mathrm{pH} 6.5), 0.5 \% \mathrm{BSA}$ and 100000 c.p.m. $\left[{ }^{125} \mathrm{I}\right]$-labelled hLH at $20^{\circ} \mathrm{C}$ for $16-20 \mathrm{~h}$ (Bramley et al., 1987). Nonspecific binding was assessed in duplicate by the inclusion of $50 \mathrm{iu}$ hCG. After incubation, tubes were chilled on ice, bound and free hormone were separated by polyethylene glycol precipitation, and the amount of ${ }^{125} \mathrm{I}$ associated with the pellet was determined at an efficiency of $75 \%$ in a multiwell Packard Crystal gamma counter. The difference between total binding and binding in the presence of excess unlabelled hormone represented specific binding. A preparation of sheep corpora lutea homogenate with a binding capacity of $5.1 \mathrm{fmol}^{\mathrm{I} 25}$ I-labelled hLH $\mu \mathrm{g}^{-\mathrm{I}}$ DNA was included as an internal standard in each assay (interassay coefficient of variation was $4.5 \% ; n=3$ ). The specificity of binding was assessed by measuring [ $\left.{ }^{125} \mathrm{I}\right]$-labelled $\mathrm{hLH}$ binding in the absence, or in the presence, of increasing concentrations of various hormones, and the concentration of each hormone required to reduce specific hLH binding by $50 \%\left(\mathrm{IC}_{50}\right)$ was calculated.

\section{Scatchard analysis}

Equilibrium constants $\left(K_{\mathrm{a}}\right)$ and maximum binding capacity were calculated by Scatchard analysis (Scatchard, 1949) of binding isotherms for ${ }^{125} \mathrm{I}$-labelled hLH binding (45-900 pg) to homogenates of corpora lutea tissue obtained at different stages of the luteal phase. Binding affinity and receptor concentration were calculated by linear regression analysis, and the number of binding sites was corrected for homogenate DNA concentration as a measure of cell content.

\section{DNA assay}

DNA was measured fluorimetrically using the method of West ef al. (1985).

\section{Statistical analyses}

All values are expressed as means \pm SEM. The significance of differences between means was assessed using Student's $t$ test. Progesterone secretion by cells from different stages of dioestrus and $\mathrm{LH}$ binding to luteal tissue homogenates at different stages of dioestrus were compared by analysis of variance (ANOVA). Values of $P<0.05$ were considered to be significant.
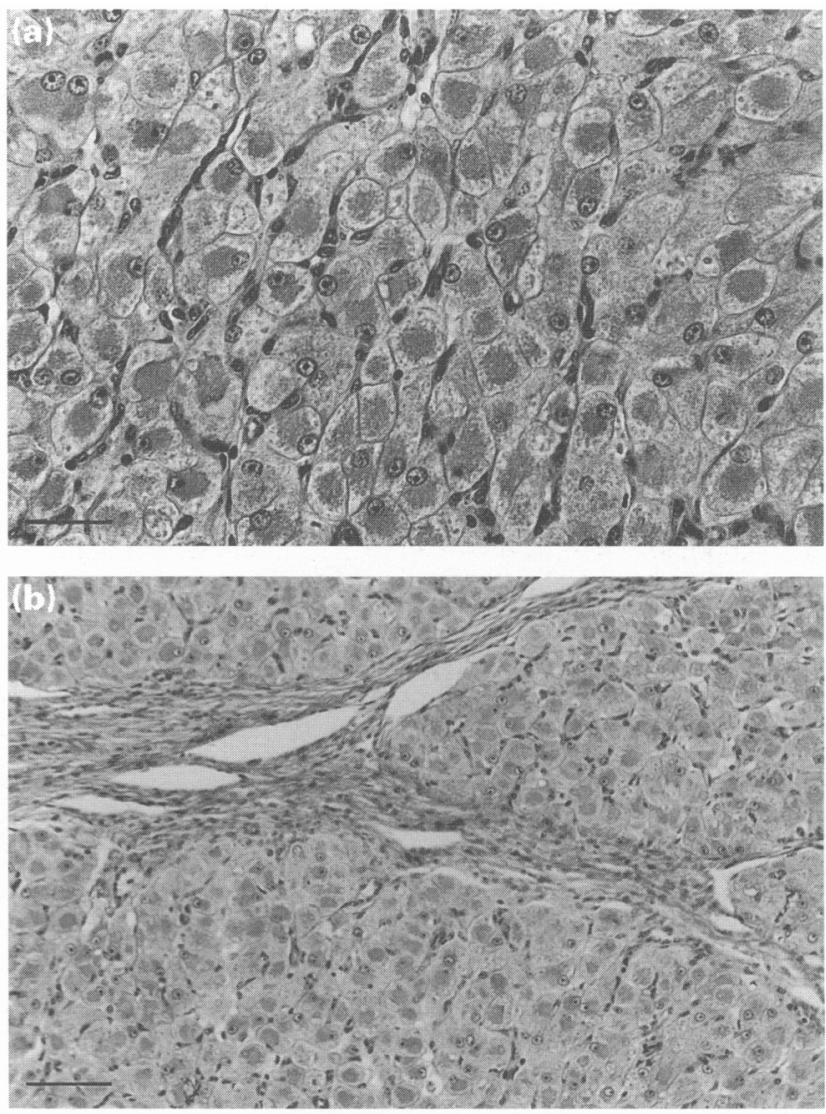

Fig. 1. Equine corpus luteum at mid-late cycle (day 10) showing (a) large cells with some small cells interspersed (scale bar represents $65 \mu \mathrm{m}$ ), and (b) trabeculae containing small elongated cells with darkly staining nuclei. Scale bar represents $140 \mu \mathrm{m}$.

\section{Results}

\section{Plasma progesterone}

Mean plasma progesterone concentrations immediately before surgery increased significantly $(P<0.01)$ between day 3 $\left(6.3 \pm 0.6 \mathrm{ng} \mathrm{ml}^{-1} ; n=6\right)$ and day $10\left(11.6 \pm 1.3 \mathrm{ng} \mathrm{ml}^{-1}\right.$; $n=13)$ but had declined by day $14\left(8.6 \pm 2.2 \mathrm{ng} \mathrm{ml}^{-1} ; n=4\right)$, although this was not a significant result $(P>0.1)$.

\section{Histology}

Three days after ovulation the corpus luteum contained substantial amounts of fibrin and blood, and in some cases still appeared to be undergoing organization in many areas. Large and small cells at this stage were $26.3 \pm 1.2 \mu \mathrm{m}$ and $9.4 \pm 1.4 \mu \mathrm{m}$ in diameter, respectively. Mid- and late-cycle corpora lutea appeared to be highly organized and consisted of areas containing large cells interspersed with small cells (Fig. 1a). These corpora lutea displayed distinct trabeculae of extracellular matrix, which contained much of the vasculature of the corpus luteum, along with some small cells (Fig. Ib). Within the trabeculae, small, elongated, nonvascular cells with darkly staining nuclei were observed. Small cells embedded 
Table 1. Ratio of large:small cells (\% $\%$ SEM) obtained by mechanical and collagenase dissociation of equine corpora lutea from different stages of dioestrus, and the cell yield (mean \pm SEM) from dissociation procedures

\begin{tabular}{|c|c|c|c|}
\hline \multirow[b]{2}{*}{ Procedure } & \multicolumn{3}{|c|}{ Stage of dioestrus (days) } \\
\hline & 3 & 10 & 14 \\
\hline \multicolumn{4}{|l|}{ Mechanical dispersion } \\
\hline Large:small cell ratio $(\%)$ & $62.5 \pm 7.2$ & $55.3 \pm 5.9$ & $45.7 \pm 4.2$ \\
\hline Cell yield $\left(10^{-7} \mathrm{~g}^{-1}\right.$ wet mass) & $2.2 \pm 1.0$ & $3.1 \pm 1.2$ & $1.4 \pm 0.5$ \\
\hline \multicolumn{4}{|l|}{ Collagenase dispersion } \\
\hline Large:small cell ratio $(\%)$ & $18.0 \pm 5.5$ & $17.1 \pm 5.5$ & $10.3 \pm 1.3$ \\
\hline Cell yield (10-7 $\mathrm{g}^{-1}$ wet mass) & $1.5 \pm 0.9$ & $1.4 \pm 0.6$ & $0.6 \pm 0.4$ \\
\hline
\end{tabular}

$n=$ at least 4 for each treatment day ${ }^{-1}$.

Large:small ratio was significantly lower for cells obtained by collagenase dispersion compared with those obtained by mechanical dispersion on each day $(P<0.01)$.

Cell yields from the two dispersion methods were not significantly different at any stage $(P>0.1)$.

within a matrix were also observed around the periphery of the corpus luteum.

By day 10, the mean diameter of large cells had increased to $36.2 \pm 1.3 \mu \mathrm{m}$, which was significantly different from that on day $3(P<0.01)$. These cells had pale-staining cytoplasm with a round nucleus containing one or more darker staining nucleoli. In some areas, the large cells were highly vacuolated. The small cells were $11.4 \pm 0.8 \mu \mathrm{m}$ in diameter and contained darkly staining nuclei. By day 14 , the morphology of the corpus luteum was not markedly different from that on day 10, except that there were signs of disruption of structural integrity, with 'empty' areas throughout the tissue.

\section{Dissociation of luteal tissue}

Although cell viability was similar for mechanically dissociated $(80-90 \%)$ and collagenase-dissociated luteal cell preparations $(70-80 \%)$, collagenase dispersion yielded significantly fewer large cells than did mechanical dissociation $(P<0.01)$ at ail stages of the luteal phase (Table 1). Histological examination of the luteal tissue remaining after mechanical dissociation showed that it was indistinguishable from intact luteal tissue, suggesting that only a small proportion of the total large cell complement had been removed by mechanical dispersion.

Cytospin preparations of cells obtained by mechanical (Fig. 2a) and collagenase (Fig. 2b) dissociation showed evidence of greater cellular damage following collagenase treatment. Staining for $3 \beta$-HSD (Fig. 3) indicated that most activity occurred in large cells (although not all large cells stained). There was no obvious correlation between stage of the luteal phase and the degree of $3 \beta$-HSD staining.

\section{Progesterone secretion}

Cells obtained by collagenase dissociation on days 3 and 14 secreted more $(P<0.01)$ progesterone than did cells obtained by mechanical dissociation of the same tissue. However, there was no significant difference in progesterone secretion between
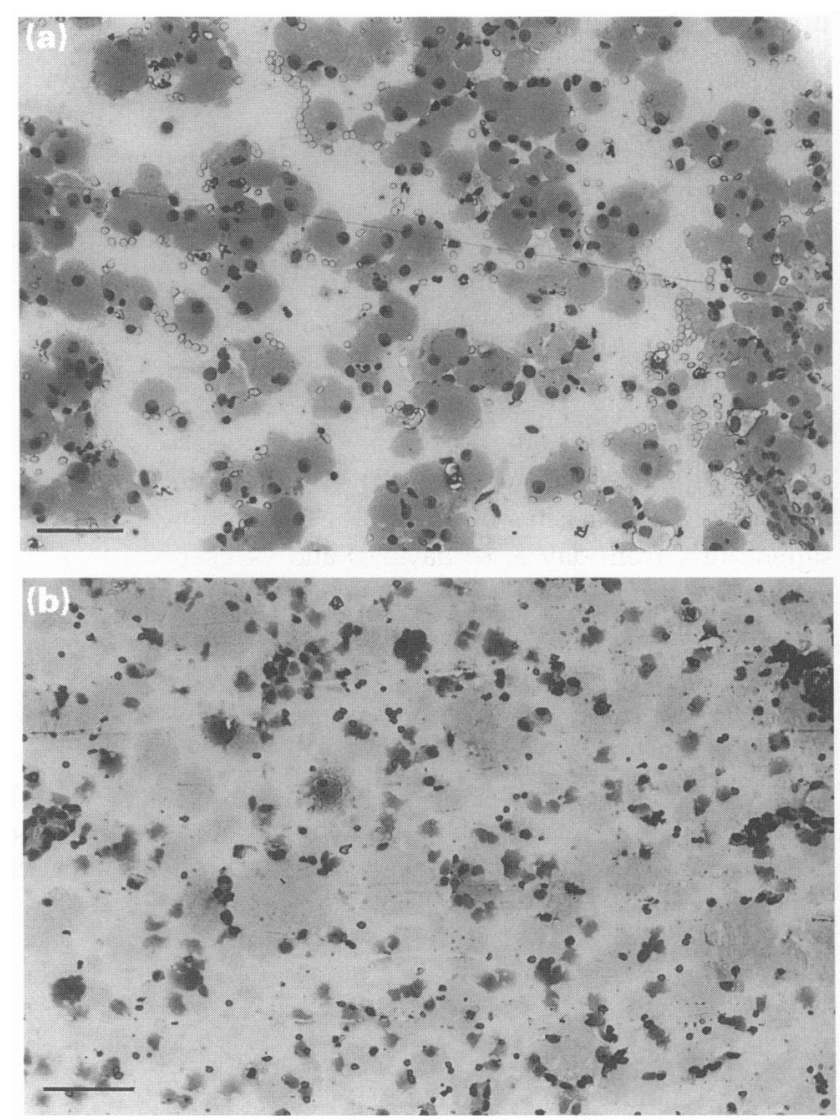

Fig. 2. (a) Mechanically dissociated cells and (b) collagenasedissociated cells from the equine corpus luteum on day 10 after ovulation. Scale bars represent $100 \mu \mathrm{m}$.

the two cell preparations from tissue obtained on day 10 (Table 2). Isolated cells from luteal tissue at days 10 and 14 after ovulation secreted significantly more progesterone $(P<0.01)$ than did cells isolated on day 3 (Table 2$)$. The addition of a range of concentrations of eLH or hCG did not alter progesterone secretion by either mechanically dissociated 


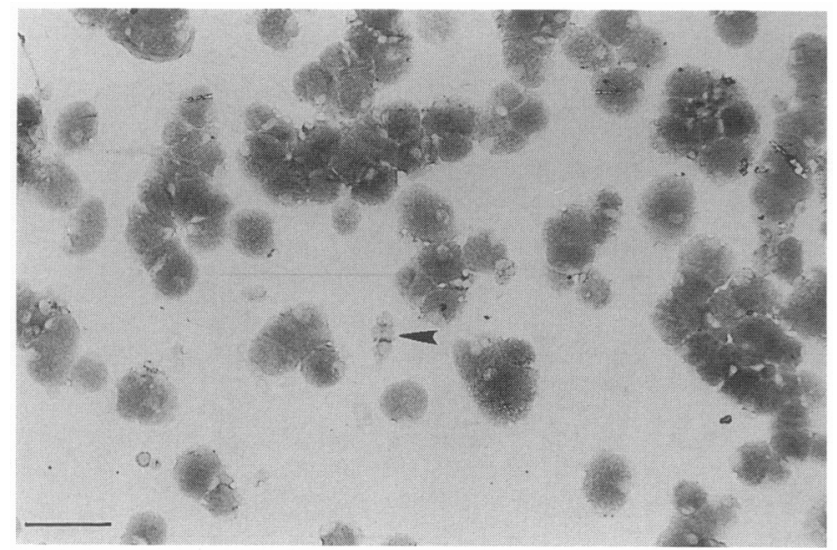

Fig. 3. Mechanically dissociated day 10 equine luteal cells stained with $\Delta^{5}, \beta$-hydroxysteroid dehydrogenase $(\beta$-HSD) (arrow indicates small cells staining negatively for $\beta$-HSD). Scale bar represents $100 \mu \mathrm{m}$.

or collagenase-dissociated cells cultured over $2-6 \mathrm{~h}$ or $20 \mathrm{~h}$ (Table 2).

\section{LH binding studies}

Specific binding of radiolabelled hLH increased linearly with increasing equine luteal homogenate concentration (Fig. 4a), and was dependent on the $\mathrm{pH}$ (Fig. 4b) and metal ion concentration of the incubation buffer (data not shown), and on the temperature and duration of incubation (Fig. 4c). Scatchard analysis of hLH binding to equine corpora lutea (Fig. 4d) revealed a single class of high-affinity $\mathrm{LH}$ binding sites. The number of binding sites and receptor affinity did not change significantly from day 3 , to days 10 and 14 (Table 3 ).

\section{Competitive binding studies}

The specificity and affinity of the equine $\mathrm{LH}$ receptor were established by binding competition studies. Highly purified hCG (CR-125) and ovine LH competed for binding of ${ }^{125} \mathrm{I}$ labelled hLH at low doses (Fig. 5a; Table 4), as did commercial hCG (Chorulon) and PMSG (Folligon) preparations (Fig. 5b; Table 4). However, higher concentrations of eLH were required to compete for hLH binding. Moreover, efSH had a similar potency to eLH, whereas microgram concentrations of ovine FSH were required to displace hLH binding (Fig. 5a). No significant competition for $\mathrm{LH}$ binding sites was observed with human or ovine prolactin, mouse EGF or the GnRH agonist buserelin (Fig. 5b).

\section{LH binding to isolated luteal cells and tissue homogenates}

The specific binding of ${ }^{125}$ I-labelled hLH to mechanically dissociated and collagenase-dissociated equine luteal cells from tissue isolated on days 3,10 and 14 of the luteal phase, and to homogenates of mare luteal tissue is shown (Fig. 6). After correction for DNA content, binding to luteal tissue homogenates and dissociated cells was not significantly different at the different stages of the luteal phase. Mechanically dissociated cells bound significantly more $(P<0.05)$ hLH than did collagenase-dissociated cells on days 10 and 14, but this difference was not significant on day 3 .

\section{Discussion}

Histological examination of the mare corpus luteum at early, mid-and late dioestrus confirmed that the morphology of this tissue is unlike that of sheep and cattle. Whereas large and small cells are highly interspersed in ruminants, there are distinct trabeculae of small cells in the mare, with small cells lying between the large cells. Although Harrison (1946) suggested that the trabeculae contained cells that had originated from the theca interna, Van Niekerk ef al. (1975) stated that only the granulosa layer contributed to the corpus luteum. Subsequent structural and functional studies have focused on the large cells in the mare corpus luteum (Levine et al., 1979; Roser and Evans, 1983), and have not considered the contribution of small cells to luteal function.

Dissociation of luteal tissue from mares yielded both large and small cells. The proportion of large cells obtained by mechanical dissociation closely resembled that reported in intact tissue by Van Niekerk et al. (1975). The relatively higher proportion of small cells observed following collagenase treatment was probably due to a combination of the release of small cells from the matrix of the corpus luteum and the

Table 2. Progesterone secretion (ng per $10^{5}$ cells $\mathrm{h}^{-1}$ ) by cells obtained by mechanical and collagenase dissociation of equine (e) luteal tissue, and the effect of treatment with eLH (100 $\mathrm{ng} \mathrm{ml}^{-1}$ ) and hCG (100 iu ml $\mathrm{ml}^{-1}$ ) (mean \pm SEM)

\begin{tabular}{|c|c|c|c|c|c|c|c|c|c|}
\hline \multirow[b]{2}{*}{ Procedure } & \multicolumn{3}{|c|}{ Day 3 of dioestrus } & \multicolumn{3}{|c|}{ Day 10 of dioestrus } & \multicolumn{3}{|c|}{ Day 14 of dioestrus } \\
\hline & Basal & $+\mathrm{eLH}$ & $+\mathrm{hCG}$ & Basal & $+\mathrm{eLH}$ & $+\mathrm{hCG}$ & Basal & $+\mathrm{eLH}$ & + hCG \\
\hline $\begin{array}{l}\text { Mechanical } \\
\text { Collagenase }\end{array}$ & $\begin{array}{r}54 \pm 7 \\
224 \pm 52\end{array}$ & $\begin{array}{r}45 \pm 14 \\
203 \pm 114\end{array}$ & $\begin{array}{r}34 \pm 11 \\
200 \pm 122\end{array}$ & $\begin{array}{r}1264 \pm 272 \\
865+181\end{array}$ & $1516 \pm 851$ & $1205 \pm 623$ & $720 \pm 118$ & $824 \pm 305$ & $338 \pm 177$ \\
\hline
\end{tabular}

$n=$ at least four experiments for each stage of the luteal phase

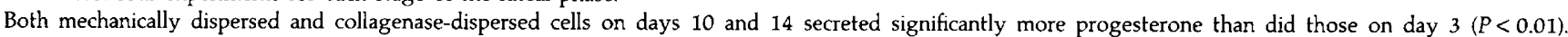

Collagenase-dispersed cells on days 3 and 14 secreted more progesterone than did mechanically dispersed cells from these days $(P<0.01)$.

On day 10 secretion of progesterone by mechanically dispersed and collagenase-dispersed cells was not significantly different $(P>0.1)$.

Addition of $\mathrm{eLH}\left(10,50,500 \mathrm{ng} \mathrm{m}{ }^{-1}\right)$ or hCG $\left(0.1,10 \mathrm{iu} \mathrm{ml}^{-1}\right)$ did not significantly increase progesterone secretion (data not shown). 

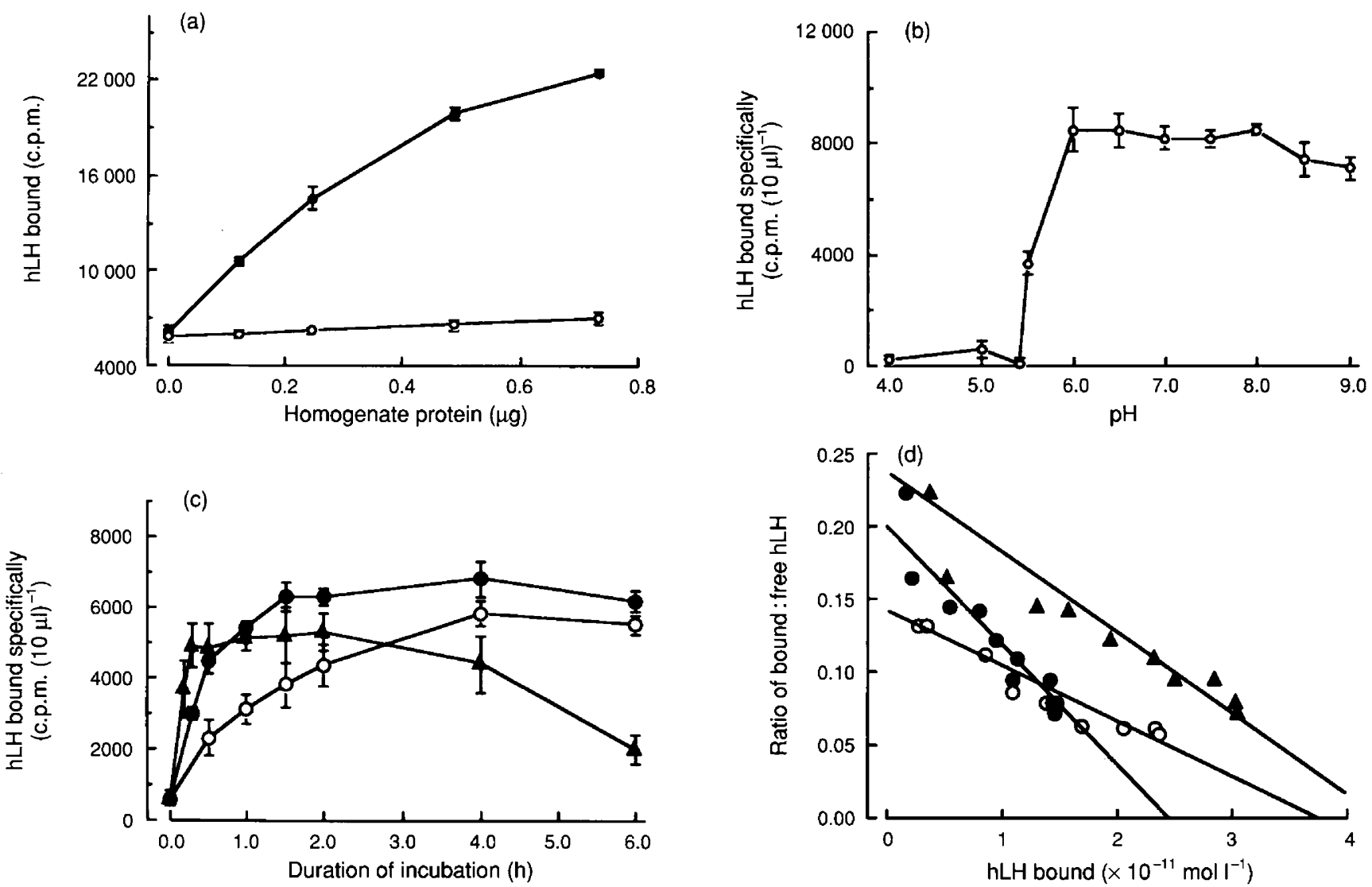

Fig. 4. Properties of the binding of ${ }^{125} \mathrm{I}$-labelled hLH tracer to equine luteal $\mathrm{LH}$ receptors. (a) Binding of hLH tracer to increasing concentrations of mare corpora lutea homogenate in the absence ( $\bullet$ ) or presence (O) of 50 iu unlabelled hCG. (b) Specific binding of hLH tracer to the corpora lutea homogenate in media at different $\mathrm{pH}$ values. (c) Specific binding of hLH tracer to mare corpora lutea homogenate following incubation for various times at either $4^{\circ} \mathrm{C}(0), 20^{\circ} \mathrm{C}(\bullet)$ or $37^{\circ} \mathrm{C}(\mathbf{\Delta})$. (d) Scatchard analyses of ${ }^{125}$-labelled hLH binding to equine luteal tissue homogenates $3(0), 10(\bullet)$ and $14(\mathbf{\Delta})$ days after ovulation. Points represent means \pm SEM for $1-5$ separate experiments performed in triplicate.

preferential destruction of large cells. Cell sizes reported here are in agreement with previously published sizes for dispersed cells (Watson and Sertich, 1990) and cells in intact tissue (Van Niekerk et al., 1975). Staining for 3 $\beta$-HSD was localized mainly to the large cells, with virtually no staining of small cells from either mechanically or collagenase-dispersed tissue; this result concurs with the localization of $3 \beta-$ HSD in granulosa cells of the preovulatory follicles of mares (Hay et al., 1975). However, it is possible that the concentrations of $3 \beta-\mathrm{HSD}$ in the small cells in our preparations were too low to be detected in this assay. In contrast to our results, Kelly et al. (1988) reported two luteal cell populations, both of which were smaller than $25 \mu \mathrm{m}$ in diameter, with the majority of $3 \beta$-HSD staining localized in a cell population measuring $7-18 \mu \mathrm{m}$ in diameter (although only $30 \%$ of the small cells stained for $3 \beta$-HSD in this study). However, these cells were obtained after up to $20 \mathrm{~h}$ of collagenase digestion, and it is likely that the fragile large luteal cells had been destroyed.

Despite the lack of obvious staining for $3 \beta-\mathrm{HSD}$ in the small cells, our results showed that both mechanically and collagenase-dispersed cells secreted progesterone. Furthermore, one of our equine luteal cell preparations, which happened to
Table 3. Number of LH binding sites and affinity constants for equine luteal tissue 3,10 and 14 days after ovulation

\begin{tabular}{lcc}
\hline Day & $B_{\max }\left(\times 10^{-11} \mathrm{~mol} \mathrm{l}^{-1} \mathrm{\mu g}^{-1} \mathrm{DNA}\right)$ & $K_{\mathrm{a}}\left(\times 10^{10} \mathrm{lmol}^{-1}\right)$ \\
\hline 3 & 4.30 & 0.382 \\
3 & 2.25 & 1.179 \\
3 & 3.73 & 0.556 \\
Mean & $3.43 \pm 0.61$ & $0.71 \pm 0.24$ \\
10 & 11.11 & \\
10 & 8.16 & 0.254 \\
10 & 2.32 & 0.764 \\
10 & 7.22 & 0.637 \\
10 & 9.83 & 0.315 \\
10 & 3.59 & 0.229 \\
Mean & $7.04 \pm 1.40$ & 0.152 \\
14 & & $0.39 \pm 0.10$ \\
& 4.75 & 0.841 \\
\hline
\end{tabular}

$B_{\max }$ and $K_{\mathrm{a}}$ on days 3 and 10 were not significantly different $(P>0.1)$. 


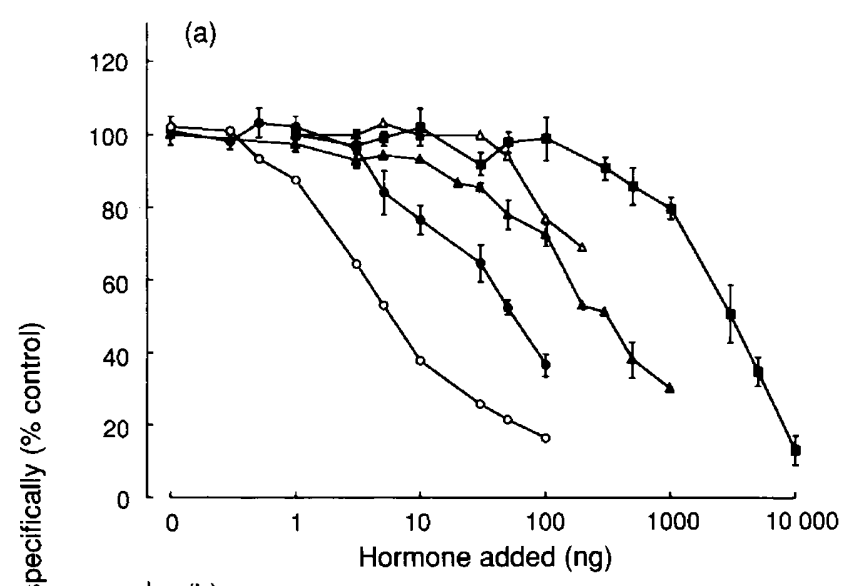

(b)

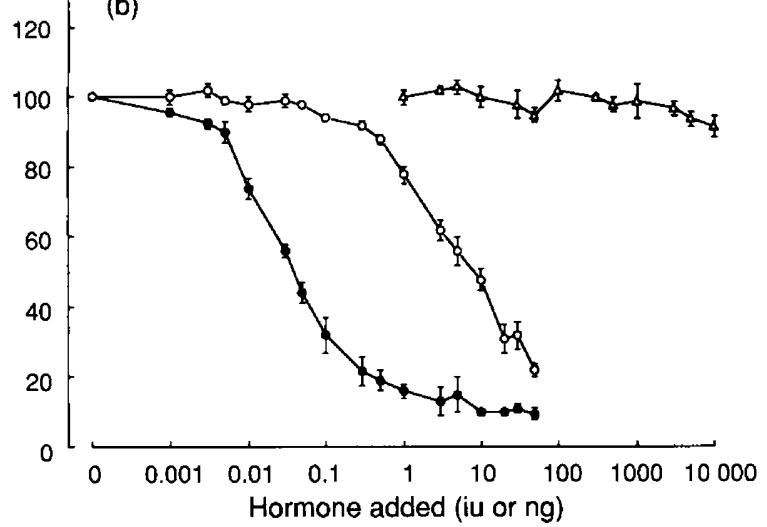

Fig. 5. Specificity of equine luteal LH binding sites. Displacement of ${ }^{125}$ I-labelled hLH with increasing concentrations of (a) hCG (CR125; o), oLH (S-23; •), eLH (E263B; 4 ), eFSH (E276B; $\triangle$ ) and oFSH (S-14; 1 ) or (b) Folligon (PMSG; ○) (iu), Chorulon (hCG; •) (iu) and mEGF, oPRL, hPRL and the GnRH agonist buserelin ( $\Delta$ ) (ng). EGF: epidermal growth factor; PRL: prolactin.

consist entirely of small cells, secreted a high concentration of progesterone (2007 ng per $10^{5}$ cells $h^{-1}$ ), indicating that at least some of the small cells derived from the corpus luteum of mares are steroidogenic.

Mechanically dispersed and collagenase-dissociated luteal cell preparations failed to respond to exogenous gonadotrophin with increased progesterone secretion. A lack of response to exogenous gonadotrophin has been reported for sheep, cattle and mare luteal cells cultured in serum-containing media (Pate and Condon, 1982; Hoyer et al., 1988; Watson and Sertich, 1990), suggesting that the cells may have been maximally stimulated by LH present in the serum (Watson and Sertich, 1990). Indeed, stimulation of progesterone secretion by LH has been reported previously for equine (Kelly et al., 1988) and rat luteal cells (Nelson et al., 1992) cultured in serum-free medium. The presence of fetal calf serum in the dissociation medium of collagenase-dispersed cells in the present study could explain the lack of stimulation by $\mathrm{LH}$, as these cells may have been maximally stimulated by this treatment. However, this does not explain why mechanically dispersed cells, which had not been exposed to fetal calf serum, were also unstimulated. Furthermore, human luteal cells isolated mechanically in media without fetal calf serum are capable of
Table 4. Concentrations required for half-maximal displacement of ${ }^{125} \mathrm{I}$-labelled $\mathrm{hLH}$ binding $\left(\mathrm{IC}_{50}\right)$ to equine luteal tissue homogenates by exogenous hormones

\begin{tabular}{lcc}
\hline Hormone & $n$ & $\mathrm{IC}_{50}$ (ng or iu) \\
\hline hCG (CR-125) & 2 & $8 \mathrm{ng}$ \\
oLH (S-23) & 2 & $60 \mathrm{ng}$ \\
eLH (E236B) & 3 & $350 \mathrm{ng}$ \\
eFSH (E276B) & 1 & $350 \mathrm{ng}$ \\
oFSH (S-14) & 1 & $2000 \mathrm{ng}$ \\
Chorulon (hCG) & 5 & $0.05 \mathrm{iu}$ \\
Folligon (PMSG) & 4 & $9.0 \mathrm{iu}$ \\
\end{tabular}

PMSG: pregnant mares' serum gonadotrophin.

Values are means of I-5 separate displacement experiments performed in triplicate.

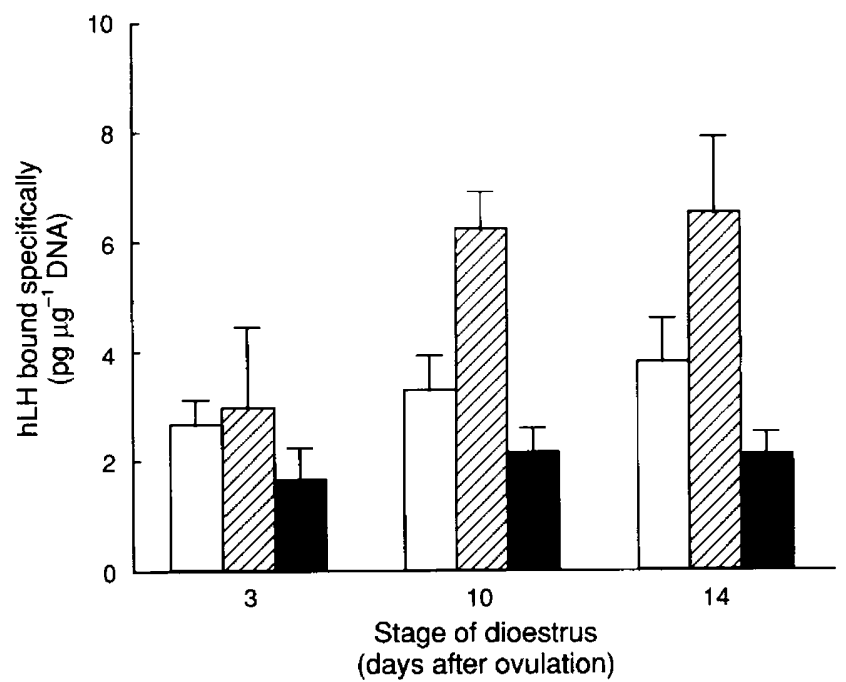

Fig. 6. LH binding to equine luteal tissue homogenate $(\square)$ and to mechanically dissociated $(\mathbb{Z})$ and collagenase-dissociated $(\boldsymbol{a})$ luteal cells at different stages of dioestrus. The average binding corresponds to tissue and cells from at least four animals, and binding was performed in triplicate on each sample. Bars represent SEM. LH binding to luteal tissue homogenates on days 3,10 and 14 of dioestrus was not significantly different $(P>0.1)$. Mechanically dissociated cells bound significantly more $(P<0.05) \mathrm{hLH}$ than did collagenasedissociated cells on days 10 and 14 .

responding to both hCG and dibutyryl cAMP (T. A. Bramley, unpublished).

Lack of responsiveness to LH did not appear to be due to a lack of $\mathrm{LH}$ receptors on mare luteal cells. Our LH binding data agree in general with those of Roser and Evans (1983), which showed a single population of high-affinity $\mathrm{LH}$ receptors on equine luteal tissue. However, there were a number of important differences between our data and those of other studies. We found that the binding of $\mathrm{LH}$ to luteal tissue and dissociated cells was not different on days 3, 10 and 14 after ovulation. In contrast, Roser and Evans (1983) described a 21-fold increase in unoccupied receptors in equine corpus luteum between day 1 and day 14 of the cycle, and studies in other species have generally described maximal $\mathrm{LH}$ binding in the mid-luteal 
phase (pigs: Ziecik et al., 1980; sheep: Diekman et al., 1978; cattle: Spicer et al., 1981; humans: Bramley et al., 1987). However, the calculations of Roser and Evans were normalized to the mass of the corpus luteum, which may have underestimated the number of LH binding sites in the early corpus luteum because of the large amount of fibrin and red blood cells present in the tissue at this stage (Pierson and Ginther, 1985). We have shown a higher degree of $\mathrm{LH}$ binding than that reported by Roser and Evans (1983) and Stewart and Allen (1979), although it is difficult to compare studies, particularly that of Roser and Evans (1983), as the units in which binding was expressed were not the same. Furthermore, the number of LH binding sites may have been significantly underestimated by other groups, since separation of bound from free hormone by centrifugation alone fails to recover all the LH-receptorhormone complexes present (Bramley, 1981).

Roser and Evans (1983) reported a fivefold increase in receptor affinity between day $I$ and day 13 , and Ziecik et al. (1980) showed that the affinity constant of the porcine luteal LH receptor increased significantly between day 10 and day 16 . However, most other studies have failed to demonstrate a change in $\mathrm{LH}$ receptor affinity in corpora lutea of other species (cattle and sheep: Diekman et al., 1978; Rao, 1979; humans: Bramley et al., 1987), and we observed no significant change in receptor affinity from day 3 , to days 10 and 14 (although binding affinity did vary markedly in different corpora lutea at the same stage of the luteal phase).

Cells obtained by mechanical dissociation of luteal tissue appeared to bind more LH than did homogenates of luteal tissue, although the difference was not significant. Mechanical dissociation of luteal tissue yielded a high proportion of large Iuteal cells, whereas tissue homogenates contain many nonluteal cells in addition to LH-binding luteal cells. Hence, expression of the number of LH receptors on a per cell (DNA) basis could account for the difference in binding between cells obtained by mechanical dissociation and tissue homogenates. Similarly, a significantly lower degree of LH binding in cells obtained by collagenase dissociation of luteal tissue on days 10 and 14 compared with mechanical dispersion may reflect the presence of other nonluteal cell types within the corpus luteum (endothelial cells and fibroblasts) that do not bind hormone but that survive cell dissociation by collagenase and increase the DNA content of the cell pellet. Since the two dissociation methods yield quite different cell populations, it is not clear at present whether mechanically dissociated cells possess more LH receptors, or whether collagenase treatment has resulted in some receptor loss or damage.

The results obtained in this study are particularly interesting for several reasons. First, large luteal cells isolated from ovine and bovine corpora lutea possess few or no LH receptors (Fitz et al., 1982; Hoyer and Niswender, 1985). However, in our study, the binding of LH to cells obtained by mechanical dissociation (with many large cells) was greater than that to cells obtained by collagenase dissociation (predominantly small cells). This suggests that large cells from the mare corpus luteum bind $\mathrm{LH}$.

Second, damage to $\mathrm{LH}$ binding sites during collagenase dispersion of equine luteal cells cannot fully explain the lack of effect of exogenous $\mathrm{LH}$ on progesterone secretion, as cells obtained by mechanical dissociation were also unresponsive to
$\mathrm{LH}$, and both cell preparations bound LH. Rather, these results suggest that luteal tissue from mares is not responsive to $\mathrm{LH}$ at the stages examined in this study or that hormonal control of the mare corpus luteum may differ from that in other species.

Third, although cells derived from the theca interna develop into small luteal cells of the corpus luteum in other species, it is believed that only the granulosa cells of the mare preovulatory follicle contribute to the fully formed corpus luteum (Van Niekerk $e t$ al., 1975). However, we have observed LH binding and progesterone secretion by collagenase-dissociated luteal tissue that contained a high proportion of small cells, suggesting that at least a proportion of small cells of the mare corpus luteum may be luteal in nature.

To our knowledge, this is the first report to compare cell populations obtained by mechanical and collagenase dissociation of luteal tissue with regard to morphology, progesterone secretion and LH binding. Most functional studies of cells from the corpus luteum have used enzymatic dissociation or a combination of methods using physical disruption of the tissue followed by enzyme treatment to increase cell yield. Although not all commercially available collagenase preparations would necessarily have the same effect, we have shown that enzymatic dissociation of the corpus luteum may provide cell populations that are unrepresentative of this tissue.

The authors thank M. Colston, C. Scudamore and A. McDonnell for assistance with palpations and surgery, and $S$. Thomson for technical assistance. This work was supported by a Wellcome Trust grant to E. D. Watson and T. A. Bramley.

\section{References}

Baird DT (1992) Luteotrophic control of the corpus luteum Animal Reproduction Science 28 95-102

Bramley TA (1981) Properties of LH/hCG receptors in porcine corpus luteum homogenates and subcellular fractions and factors influencing the recovery of membrane-bound hormone Molecular and Cellular Endocrinology 24 29-40

Bramley TA, Stirling D, Swanston IA, Menzies GS, McNeilly AS and Baird DT (1987) Specific binding sites for gonadotrophin-releasing hormone, $\mathrm{LH} /$ chorionic gonadotrophin, low density lipoprotein, prolactin and $\mathrm{FSH}$ in homogenates of human corpus luteum: II Concentrations throughout the luteal phase of the menstrual cycie and early pregnancy Journal of Endocrinology 13 317-327

Condon WA and Black DL (1976) Catecholamine-induced stimulation of progesterone by the bovine corpus luteum in vitro Biology of Reproduction 15 $573-578$

Condon WA, Ganjam VK and Kenney RM (1979) Catecholamines and equine luteal progestagens Journal of Reproduction and Fertility Supplement 27 199-203

Diekman MA, O'Callaghan PO, Nett PM and Niswender GD (1978) Validation of methods and quantification of luteal receptors for $\mathrm{LH}$ throughout the oestrous cycle and early pregnancy in ewes Biology of Reproduction 19 999-1009

Fitz A, Mayan MH, Sawyer HR and Niswender GD (1982) Characterization of two steroidogenic cell types in the ovine corpus luteum Biology of Reproduction 27 703-711

Harrison RJ (1946) The early development of the corpus luteum in the mare Journal of Anatomy 80 160-168

Hay MF, Allen WR and Lewis IM (1975) The distribution of $\Delta^{5}-3 \beta$ hydroxysteroid dehydrogenase in the Graafian follicle of the mare Journal of Reproduction and Fertility Supplement 23 323-327

Hoyer PB and Niswender GD (1985) The regulation of steroidogenesis is different in the two types of ovine luteal cells Canadian Journal of Physiology and Pharmacology 63 240-248 
Hoyer PB, Kong W, Crichton EG, Bevan L and Krutzsch PH (1988) Steroidogenic capacity and uitrastructural morphology of cultured ovine luteal cells Biology of Reproduction 38 909-920

Kelly CM, Hoyer PB and Wise ME (1988) In vitro and in vivo responsiveness of the corpus luteum of the mare to gonadotrophin stimulation Journal of Reproduction and Fertility 84 593-600

Koos RD and Hansel W (1981) The large and small cells of the bovine corpus luteum: Ultrastructural and functional differences. In Dynamics of Ovarian Function, pp 197-203 Eds NB Schwartz and M Hunzicker-Dunn. Raven Press, New York

Lemon $M$ and Loir $M$ (1977) Steroid release in vitro by two luteal cell types in the corpus luteum of the pregnant sow Joumal of Endocrinology 72 351-359

Levine $\mathbf{H}$, Wight $\mathrm{T}$ and Squires $\mathbf{E}$ (1979) Ultrastructure of the corpus luteum of the cycling mare Biology of Reproduction 20 492-504

Nelson SE, McLean MP, Jayatilak PG and Gibori G (1992) Isolation, characterization and culture of cell subpopulations forming the pregnant rat corpus luteum Endocrinology 130 54-66

O'Shea JD, Rodgers RJ and D'Occhio MJ (1989) Cellular composition of the cyclic corpus luteum of the cow Journal of Reproduction and Fertility $\mathbf{8 5}$ 483-487

Pate JL and Condon WA (1982) Effects of serum and lipoproteins on steroidogenesis in cultured bovine luteal cells Molecular and Cellular Endocrinology 28 551-562

Payne AM, Downing JR and Wong K-L (1980) Luteinizing hormone receptors and testosterone synthesis in two distinct populations of Leydig cells Endocrinology 106 1424-1429

Pierson RA and Ginther OJ (1985) Ultrasonic evaluation of the corpus luteum of the mare Theriogenology 21 471-483

Rao Ch V (1979) Differential properties of human chorionic gonadotrophin and human luteinizing hormone binding to plasma membranes of bovine corpora lutea Acta Endocrinologica 90 696-710

Roser JF and Evans JW (1983) Luteal luteinizing hormone receptors during the postovulatory period in the mare Biology of Reproduction 29 499-510

Rotman B and Papermaster BW (1966) Membrane properties of living mammalian cells as studied by enzymatic hydrolysis of fluorogenic esters Proceedings of the National Academy of Sciences USA 55 134-141
Scatchard G (1949) The attractions of proteins for small molecules and ions Annals of the New York Academy of Sciences 51 660-672

Simmons KR, Caffrey JL, Phillips JL, Abel H and Niswender GD (1976) A simple method for preparing suspensions of luteal cells Proceedings of the Society for Experimental Biological Medicine 152 366-371

Spicer LJ, Ireland JJ and Roche JF (1981) Changes in serum LH, progesterone and specific binding of ${ }^{125} \mathrm{I}-\mathrm{hCG}$ to luteal cells during regression and development of bovine corpora Iutea Biology of Reproduction 25, 832-841

Stewart F and Allen WR (1979) The binding of FSH, LH and PMSG to equine gonadal tissues Journal of Reproduction and Fertility Supplement 27 431-440

Van Niekerk CH, Morgenthal JC and Gerneke WH (1975) Relationship between the morphology of and progesterone production by the corpus luteum of the mare Journal of Reproduction and Fertility Supplement 23 171-175

Watson J and Leask JTS (1975) Superfusion in vitro in the study of ovarian steroidogenesis Joumal of Endocrinology 64 163-173

Watson ED and Sertich PL (1990) Secretion of prostaglandins and progesterone by cells from corpora lutea of mares Journal of Reproduction and Fertility $\mathbf{8 8}$ 223-229

Webb R., Baxter G, McBride D, Nordblum GD and Shaw MPK (1985) The measurement of testosterone and oestradiol-17 $\beta$ using iodinated tracers and incorporating an affinity chromatography extraction procedure Journal of Steroid Biochemistry 23 1043-1051

West DC, Sattar A and Kumar S (1985) A simplified in situ solubilization procedure for the determination of DNA and cell number in tissue cultured mammalian cells Analytical Biochemistry 47 289-295

Wiltbank MC and Niswender GD (1992) Functional aspects of differentiation and degeneration of the steroidogenic cells of the corpus luteum in domestic ruminants Animal Reproduction Science 28 103-110

Ziecik A, Shaw HJ and Flint APF (1980) Luteal LH receptors during the oestrous cycle and early pregnancy in the pig Jourmal of Reproduction and Fertility 60 129-137 